\title{
Некоторые международно-правовые аспекты сотрудничества Мексики и США в области борьбы с торговлей наркотиками
}

\section{A.A. Мищаков*}

Проблема борьбы с незаконным оборотом наркотиков в настоящее время является для России чрезвычайно актуальной. За последнее десятилетие страна из относительно благополучной превратилась в крупнейший регион потребления и продажи наркотических средств.

Несмотря на организационные и практические меры правоохранительных органов и системы здравоохранения, а также усилия антинаркотических общественных организаций, эксперты признают, что наркологическая ситуация в России ухудшается и в 2000 г. достигла своего пика.

В связи с этим для нас представляет интерес опыт других стран, в частности стран американского континента, столкнувшихся с грозным явлением распространения наркотиков значительно раньше.

В межгосударственных отношениях Мексики и США проблема торговли и потребления наркотиков является одним из основных вопросов национальной безопасности и осуществления правосудия, в связи с чем в свое время правительства стран предприняли ряд кардинальных шагов, направленных на объединение усилий для совместного решения проблемы.

В частности, в течение 90-х годов двустороннее мексиканско-американское сотрудничество в этой области развивалось в самых различных формах, что содействовало не только укреплению контактов, но и существенным позитивным результатам в контроле за наркотиками и осуществлении правосудия 1 .

Международно-правовая основа сотрудничества представлена в следующих соглашениях:

1. Об исполнении уголовных наказаний, 1976г.

2. Об экстрадиции, 1978г.

3. О возвращении автотранспортных и авиатранспортных средств, украденных или незаконно использовавшихся, 1981r.

4. О сотрудничестве в оказании взаимной помощи в юридической сферe, 1987r.

\footnotetext{
* Соискатель кафедры международного права МГИМО (У) МИД РФ.

1 International Narcotics Control Strategy Report (Mexico) 1999, www.state.gov
} 
5. О сотрудничестве в борьбе с торговлей наркотиками и наркотической зависимостью, 1989г.

6. О сотрудничестве в обмене информацией о финансовых операциях, осуществляемых через финансово-кредитные организации, для борьбы с незаконной деятельностью, 1995г.

На основе этих документов сотрудничающие стороны взаимодействуют с учетом строжайшего соблюдения принципа национального суверенитета и территориальной юрисдикции Мексики и США.

Сознавая масштабы угрозы торговли наркотиками для национальной безопасности обеих стран, желая придать высокий политический уровень двустороннему сотрудничеству в этой области, президенты США и Мексики приняли решение о создании в марте 1996 г. Контактной группы на высоком уровне по контролю за наркотиками, в состав которой вошли ключевые должностные лица, ответственные за проведение антинаркотической политики в своих странах.

Деятельность Группы способствует взаимному доверию и уважению между представителями правоохранительных органов сотрудничающих стран. Для осуществления этой деятельности в рамках Контактной группы создано шесть рабочих групп по следующим направлениям совместной работы : юридические вопросы и осуществление правосудия; совместные экспертные оценки; уменьшение спроса на наркотики; незаконная торговля оружием; отмывание денег; контроль за химическими веществами.

Сотрудничество Мексики и США в уголовной сфере является наиболее развитым и разносторонним. Первое изложение совместного видения борьбы с торговлей наркотиками осуществлено в совместном докладе "Мексика и США перед проблемой наркотиков: совместное исследование" 2 .

На основании глубокого анализа процессов наркоторговли и наркозависимости документ предупреждает об опасности для наций в связи с ростом спроса на наркотики, о производстве и транспортировке наркотиков в Мексике и США, о незаконной торговле оружием через общую границу, о социальных последствиях этого явления для обеих стран.

Совместное исследование послужило основой для разработки двусторонней стратегии борьбы с наркотиками и координированной политики в решении данной проблемы. Такая стратегия изложена в подписанной президентами стран в мае 1997г. Декларации об альян-

2 Amenaza el fracaso a la guerra de Fox contra las drogas// Financiero. 09/01/2001 
се Мексика - США для борьбы с наркоторговлей -как бы в дополнение к национальным программам каждой страны.

Деятельность Альянса охватывает все аспекты проблемы контроля наркотиков и обязывает национальные антинаркотические организации разработать политику по каждому из следуюших вопросов:

уменьшение спроса на наркотики;

уменьшение производства и распространения наркотиков;

осуществление правосудия против организованной преступности;

защита должностных лиц - сотрудников правоохранительных органов; двустороннее сотрудничество и координация политики в сфере осуществления правосудия;

поиск бежавших преступников; экстрадиция; протокол к Соглашению о выдаче с целью установления временной выдачи;

борьба с незаконной торговлей оружием. Соглашение для Западного полушария;

специальная сессия Генеральная Ассамблеи ООН 1998 г;;

борьба с коррупцией путем усиления демократических институтов; приграничное сотрудничество;

контроль за химическими веществами;

конфискация собственности, принадлежащей наркоторговцам;

наземный, воздушный и морской перехват наркотиков;

обучение лиц, участвующих в борьбе с наркотиками, и техническое сотрудничество; обмен информацией и доказательствами.

Правительства Мексики и США решили установить показатели уровня эффективности для перечисленных задач с целью оценки деятельности каждой из сотрудничающих сторон ${ }^{3}$.

Как уже отмечалось, в рамках Альянса для борьбы с наркоторговлей, правительства Мексики и США разработали двустороннюю стратегию (от 8.02.1998г.), которая дополняет национальные стратегические программы и объединяет усилия обеих стран в контроле за потреблением, производством и торговлей наркотиками, а также в области борьбы с преступлениями, связанными с наркотиками - отмыванием денег и незаконной торговлей оружием.

В качестве основных принципов взаимодействия стратегия утверждает уважение суверенитета и юрисдикции каждой страны, признание совместной ответственности в том, что касается наркотиков, необходимость применения комплексного подхода к проблеме, взаимность и равновесие в действиях, предпринимаемых в области осуществления правосудия.

3 Identifican seis grandes rutas del narcotrafico // Universal. 15/11/20000. 
Пленарная группа по осуществлению правосудия в двустороннем сотрудничестве по наркотикам занимает как бы второе положение после Контактной группы на высоком уровне по степени представительства и по значимости принимаемых ею решений. Основной ее целью является разработка стратегии в области обмена информацией и юридического сотрудничества, генеральные прокуроры обеих стран координируют ее деятельность.

Первое заседание группы по правосудию состоялось 7 февраля 1995г. под названием "Предварительная встреча представителей Генеральной прокуратуры Мексики и Министерства юстиции США по оперативным вопросам". В дальнейшем заседания проходят регулярно 4-5 раз в год поочередно в Вашингтоне и Мехико.

В последние годы укрепились связи между Генеральной прокуратурой Мексики и спецслужбами США - Агентством по борьбе с наркотиками (ДЕА), Таможенной службой и ФБР по вопросам борьбы с транспортировкой наркотиков, особенно в приграничных районах.

В соответствии с Меморандумом о взаимопонимании от 31 июля 1996 г. для осуществления совместных действий в приграничной зоне были созданы специальные приграничные совместные группы, состоящие из сотрудников Федеральной оперативной полиции Мексики, ДЕА, ФБР и Таможенной службы США. Целями и задачами групп является расследование и получение возможно полной информации, связанной с членами и modus operandi крупнейших мексиканских наркокартелей, поддержание постоянного обмена информацией с соответствующими структурами связи в ДЕА, ФБР, Таможенной службе.

Приграничные группы размешаются на территории Мексики в г.г. Тихуане, Сьюдад-Хуаресе, Монтеррее и Гвадалахаре ; также имеются пять филиалов, в частности, группа Тихуана имеет филиалы в Мехикали и Сан-Луис-Рио-Колорадо; группа Монтеррей - в Рейносе и Матаморосе; группа Гвадалахара - в Колиме.

Среди успешных операций этих спецгрупп последнего времени следует упомянуть задержание братьев Амескуа, руководителей картеля Гвадалахары, а также совместную с ДЕА операцию в Сан-Луис-Рио-Колорадо по конфискации крупных партий наркотиков 4 .

Для обеспечения более тесных контактов в совместных действиях Генеральная прокуратура Мексики имеет свое представительство в Вашингтоне и два региональных представительства в Лос-Анжелесе и в Сан-Антонио с филиалами в Сан-Диего и Эль Пасо.

44 Lopez J., Narcoamenaza, Glijalbo, 2000 
Кроме того с сентября 1998 г. в соответствии с соглашениями, достигнутыми на Первом заседании Контактной группы на высоком уровне в марте 1997г., представитель Генеральной прокуратуры Мексики работает в Калифорнии (г. Риверсайд) в тесном контакте с Центром авиаперехвата Минфинансов США.

Мексиканские пилоты из Представительства в Сан-Антонио, прикомандированные к Центру наблюдения Таможенной службы США (г. Корпус Кристи) осуществляют радарный контроль и координируют с мексиканской стороной меры по перехвату и контролю за торговлей наркотиками, а также по обмену информацией 5 .

В период 1998-2000 г.г. усилился процесс экстрадиции между двумя странами, особенно лиц, причастных к торговле наркотиками. За это время США представили 60 запросов о выдаче, а Мексика - 58. Процент выдачи с мексиканской стороны составляет $65 \%$, с американской стороны - $48 \%$.

В этой связи представляют интерес международно-правовые основы выдачи мексиканских граждан в США.

Выдача мексиканских граждан регулируется ст. 14 Закона "О международной выдаче": "Никакой мексиканский гражданин не может быть выдан иностранному государству, кроме исключительных случаев, по которым принимает решение исполнительная власть страны".

Статья 9 Договора между Мексикой и США об экстрадиции от 4 мая 1978r. предусматривает: "Ни одна из сторон не обязана выдавать своих граждан, но исполнительная власть Запрашиваемой стороны имеет право, если это не противоречит законам, осуществлять выдачу, если, по ее мнению, есть такая необходимость".

В период правления Президента Седильо в Мексике, в целях усиления борьбы с организованной преступностью, регулярно осуществлялись меры по выдаче мексиканских граждан за совершение различных преступлений, в основном, связанных с торговлей наркотиками.

Для более эффективного сотрудничества в этих вопросах, Мексика и США подписали Дополнительный протокол от 17 ноября 1997г., позволяющий осуществлять временную экстрадицию обвиняемого для судебного процесса в стране, направившей запрос, до того, как это лицо отбудет наказание в запрашиваемой стране.

Протокол меняет название ст. 15 Договора об экстрадиции от 4 мая 1978г., на "Временная выдача" и добавляет два следующих пункта:

5 EU dara a conocer hoy lista de jefes narcos // Sol de Mexico, 01.06 .2000 
"2. Запрашиваемая сторона после получения запроса на выдачу, сформулированного в соответствии с данным Договором, может временно выдать лицо, получившее обвинительный приговор в Запрашиваемом государстве, с целью, чтобы данное лицо было подвергнуто уголовному процессу в государстве, направившем запрос, до или во время отбывания срока обвинительного приговора, вынесенного Запрашиваемым государством. Лицо, выданное таким образом, должно находиться под стражей в государстве, направившем запрос, и должно быть возвращено Запрашиваемой стороне по окончанни процесса в соответствии с условиями, установленными по взаимной договоренности между сторонами, для таких ситуаций.

3. В случаях, когда лицо, выданное временно, получает оправдательный приговор в государстве, направившем запрос, время его пребывания под стражей в государстве, направившем запрос, засчитывается при исчислении срока наказания в Запрашиваемом государстве."

Дополнительный протокол позволяет подвергать судебному преследованию лиц, совершивших противоправные действия в одной из двух стран, в то время как они отбывают заключение в другой, и таким образом избегать задержек, которые во многих случаях усложняют ход судебного процесса.

Со своей стороны, Генеральная прокуратура Мексики, с целью избежать случаев безнаказанности, когда по какой-либо причине невозможно произвести выдачу, начинает уголовное преследование, основываясь на статье 4 Федерального уголовного кодекса, которая относит к компетенции мексиканских властей вынесение решения по преступлениям, совершенным за границей и предусматривает следующее :

"Преступления, совершенные на иностранной территории мексиканским гражданином против мексиканских граждан или против иностранных граждан, или иностранным гражданином против мексиканских граждан, подлежат уголовному преследованию на территории Республики в соответствии с федеральными законами, если подпадают под следующие требования:

1. Обвиняемый находится на территории Республики;

2. Обвиняемый не подвергался уголовному преследованию за данное преступление в стране совершения преступления;

3. Противоправное действие является преступным в стране совершения этого деяния и в Мексике. ${ }^{\prime \prime}$

6 Saavedra H., Carteles de Mexico // Poliforum, 1999. 
Генеральные прокуроры Мексики и США подписали 2 июня 1998г. еще один документ, регламентирующий совместную политику в области правосудия, так называемое Совместное Письмо, адресованное президентам обеих стран, и подтверждающее следующие обязательства:

1. Заранее сообщать о любых действиях в сфере осуществления правосудия, которые могут иметь последствия для другой страны, с целью предварительного установления законности таких действий.

2. Информировать о действиях в сфере осуществления правосудия, которые, хотя и производятся на территории третьей страны, могут также иметь последствия для Мексики или СШІА.

3. Развивать программы обучения для должностных лиц для ознакомления с юридическими системами и техникой ведения расследований в обеих странах;

4. Подтвердить действие норм 1992 года, установленных для представителей иностранных правоохранительных органов, аккредитованных в Мексике на постоянной основе;

5. Установить прямую линию между генеральными прокурорами обеих стран для более простой и быстрой связн.

Одним из разделов данного документа (п. 3) является совместная программа подготовки сотрудников федеральных правоохранительных органов США и Мексики, которая предусматривает ознакомление с юридическими нормами и техникой расследования обеих стран, ставит задачу дать слушателям более широкое представление о юридических системах, структуре и формах применения законодательства в США и Мексике ${ }^{7}$. В работе первого семинара по программе обучения, который состоялся в ноябре 1998г., с мексиканской стороны приняли участие сотрудники Федеральной оперативной полиции, Генпрокуратуры, а также представительств Генпрокуратуры в Вашингтоне, Лос-Анжелесе, Сан-Диего и Сан-Антонио. На семинаре обсуждались вопросы прослушивания частных переговоров, изъятия и конфискации собственности и предметов, служивших для совершения преступлений, сбора и представления доказательств в рамках мексиканского законодательства.

Рассматривая отдельные стороны мексиканско-американского сотрудничества в области контроля за наркотиками, особенно его международно-правовые основы , можно отметить, что особенный интерес для нашей страны представляют совместные юридические документы и практические меры по улучшению ситуации с экстрадицией граждан и общей координацией действий правоохранительных органов. Впол-

${ }^{7}$ McCafrey fracaso en Mexico //Universal. 15.02.2000/ 
не очевидно, что в дальнейшем на фоне международной консолидации стран против глобальной угрозы ведушая роль России в решении проблемы наркотиков в регионе СНГ не только сохранится, но усилится. 